\title{
6
}

\section{On the miracles in Bacon's New Atlantis}

\author{
JERR Y W EIN BER GER
}

Bacon's New Atlantis depicts the world to be produced by his famous project for modern science and technology and the consequent mastery of nature and 'relief of man's estate'. The sailors who come upon the island leave a world where they are buffeted by the destructive forces of nature - wind, calm, famine, and disease - and enter one where the weather is controlled, needs met, and sickness cured. The key element of Bensalemite history is the founding by King Solamona, nineteen hundred years prior to the sailors' visit, of Salomon's House. This institution, a technological-scientific think tank, is described as the 'noblest foundation' ever on earth. It is the light of Bensalem and 'dedicated to the study of the works and creatures of God', and source of 'the knowledge of causes, and secret motions of things; and the enlarging of the bounds of human empire [and] ... effecting of all things possible'. It is, in other words, the engine of otherwise unheard material progress and human self-reliance. ${ }^{\mathrm{I}}$

Even so, the story opens with the intimation that the sailors' rescue from dire straits at sea - their coming upon Bensalem - is a miracle, God's answer to their prayer that he 'discover' land to them just as he had 'discovered the face of the deep' in 'the beginning'. At least as far as the sailors are concerned, human self-reliance is not itself self-starting or a bootstrap phenomenon, but rather depends on divine intervention. Moreover, the society founded on science and technology has not forgotten the power 
and presence of God. While at first the sailors are suspicious and afraid of their extraordinary hosts, and not without apparent reasons, they soon come to see their hosts as benevolent and humane. They do so in large part because of the overt displays of religion, in particular Christianity, in their hosts' initial behaviour and in so many aspects of Bensalemite life and society. The Bensalemites' first communication with the sailors is in the form of a document, presented by an officer, warning them not to land but festooned with a cross and cherubim's wings. While finding the warning disturbing, the sailors were comforted by the sign of the cross, which they found 'a certain presage of good'. When approached soon after by a high-ranking Bensalemite, the first question asked by him of the sailors is whether they were Christians, after which they are asked to swear, by the Saviour Jesus and his merits, that they are not pirates. In Bensalem, Christian priests serve as officers of the state $(38-9,44)$.

There are some apparently good reasons for thinking that Bacon believed human beings could not live by technology alone and, rather, need religion as much as they need the conquest of nature. The first is a matter of general impression: there is just something unsettling and even creepy about the Bensalemites. They refuse well-meaning tips. They show gushing, teary-eyed hospitality and tenderness toward strangers. Their military history involves no killing. The people are always standing in orderly rows. The name of the one Bensalemite city mentioned, Renfusa, means 'sheep natured'. The chief festival, the Feast of the Family, honours primarily the father of the family called the Tirsan, a name derived from the Persian word for 'timid'. At this festival they declare in unison 'happy are the people of Bensalem'. Everything has its complicated ritual. Indeed, the sailors say that they have come to a 'land of angels' $\left(39^{-} 4^{\mathrm{I}}, 4^{2-}-3,45^{-}\right.$, 6o-4). In short, the Bensalemites appear to have been denatured. Their happiness seems that of contented cows (or, to speak more accurately, sheep), their orderliness lobotomised. On the one hand, we wonder how much more like zombies they would be without the spiritualising effects of their religiosity. On the other hand, perhaps these super-flat souls need even more softening, by Christianity, for them safely to possess the extraordinary powers of technology. 
Other reasons are more concrete and reveal much that is fishy about the Bensalemites' exceeding niceness and humanity. Two examples will suffice. Since the Bensalemites secretly spy on the rest of the world but are themselves undiscovered, and since they can control the weather, it is entirely possible that the sailors' happening on the island was no accident. It is possible, in other words, that the Bensalemites, for their own ends, forced the sailors to the island. The narrator of the story reports that the sailors were first unnerved by their confinement by the Bensalemites. Not convinced of their hosts' declarations of hospitality, the sailors feared unwelcome surveillance and worried that they should mind their behaviour lest some harm befall them. Later, the sailors are told that they may anticipate a long and enjoyable stay because their quarters - called the Strangers' House - is well stocked since it has been thirty-seven years since anyone has visited the island. When still later the Bensalemite 'laws of secrecy', restricting travel in and out of the island, are explained, the sailors are told that no strangers have been detained against their will, that no visiting ship has ever chosen to leave, that but thirteen individuals have left in Bensalemite ships, and the sailors 'must think' that whatever those few who returned reported would have been 'taken where they came from but for a dream'. That the sailors 'must think' this latter fact does not make it true. Moreover, according to the account of the laws of secrecy, King Solamona, who promulgated these laws, ordained the kindly treatment of visitors because it was 'against policy' that strangers should return and 'discover their knowledge' of Bensalem. Contrary to what the sailors are told they must think, the fact is that the laws of secrecy, intended to protect the island from foreign moral corruption, presume the credulousness of non-Bensalemites. If Bensalemite laws and policy were consistent, strangers unwilling to stay - or judged unfit to stay - would have to be restrained by force or killed. The sailors' initial trepidation was not without warrant $\left(4^{2}-6,5 \mathrm{I}-9,72\right)$.

Towards the end of the story the sailor-narrator converses with a Bensalemite Jew, described as a wise man and 'learned and of great policy and excellently seen in the laws and customs' of Bensalem. The narrator asks for clarification of an extraordinary Bensalemite ceremony - the Feast of the Tirsan - that honours 
especially fecund Bensalemites. The narrator comments that population increase seems to be valued by the Bensalemites and, given that fact, wonders if the Bensalemites practise polygamy. To these questions, the wise Jew describes Bensalem as the 'virgin of the world' and launches a tirade against European sexual morality, where red light districts and brothels have 'put marriage out of office'. The Jew then reports on the Bensalemites' marriage laws, which include a prohibition against polygamy, a one-month waiting period, a penalty for marrying without parental permission, and the strange institution called Adam and Eve's Pools. These pools, located near every town, are for solving the problem of post-nuptial disappointment caused by 'many hidden defects in men and women's bodies'. The Jew remarks that the Bensalemite arrangement is superior to that described by 'one of your men' in a 'feigned commonwealth, where the married couple are permitted, before they contract, to see one another naked'. Thinking the practice a good idea in principle, but that 'it is a scorn to give refusal after so familiar knowledge', the Bensalemites allow a friend of the man and a friend of the woman 'to see them severally bathe naked' $\left(64^{-8}\right)$.

The feigned commonwealth referred to by the Jew is probably More's Utopia, although it could also be, less probably, Plato's Magnesia. ${ }^{2}$ In either case, however, it is hard to see how Bensalem's practice of pre-nuptial review is an improvement over either one. In Utopia, a responsible and respectable woman presents the naked woman - whether a virgin or a widow - to the man, and some respectable man presents the naked male suitor to the prospective bride. In Magnesia, boys and girls will see each other frequently and in common in naked play, although only within limits set by a moderate sense of shame. In Utopia, Magnesia, and Bensalem the purpose of pre-nuptial review is to ensure informed and mistake-free matches. And in Utopia and Bensalem the ultimate purpose is to prevent adultery and promiscuity and, by clear implication, the conflict and social disruption that ensue from these vices. We surely have to wonder how, in Bensalem, this end is served by having friends - not even identified as to gender - act as the agents of the naked review. In stark contrast to both Plato and More, no mention is made here of the character of the agent or the conditions of the viewing. 
Surely accuracy calls for the male to be judged from the woman's point of view, and vice versa, and what is to prevent the agent, moved by inflamed desire, from falsely reporting and pursuing for himself or herself the object of desire? And what is to prevent the coveting of one's friend's spouse after such familiar knowledge? As described, the Bensalemite practice of pre-nuptial review appears so poorly contrived as to produce the opposite of its intended effect.

Moreover, only a blockhead could miss the following: the character who describes the bizarre institution is named Joabin after the vicious Joab who, among other perfidies, helped King David murder Uriah the Hittite. As every schoolboy knows, David saw Uriah's wife Bathsheeba bathing naked. David was moved by the sight to kill Uriah and marry Bathsheeba, a sin that evoked the momentous prophecy of Nathan. The Bensalemite institution of the Adam and Eve's pools is modelled on the circumstances of David's temptation and related by the namesake of the agent of David's sin. Are we to conclude that Bensalem, with its science and technology, has turned Joab into an angel and solved the problem of unruly human desire? Or does Bacon wish rather to say that the human soul is always crooked wood that cannot be straightened by technology?

The Bensalemites' general creepiness, the ominous threat suggested by Bensalem's laws of secrecy, and the moral ambiguity of Joabin's account of the Adam and Eve's pools, all suggest a decidedly mixed Baconian message about the technological future: that the conquest of nature may just as likely be for ill as for good. Bensalem seems haunted by the problems of the soul debased by materialism, bad means used for good ends, and the lawless use of technological power. The New Atlantis suggests the problem, as much as the promise, of technology and the story raises questions about the ways and means of the scientific project, the ends and the limits of the conquest of nature, and the implications of science and technology for human life and values. Nothing in the New Atlantis tells us where the guiding principles of the technological project come from, with the exception of the Christianity that so pervades Bensalem.

Moreover, modern science needs Christianity for more than just its moral compass. We learn in the story that while natural 
science, as represented by Salomon's House, was founded well before the arrival of Christianity to Bensalem, the House of Salomon was named after the King of the Hebrews by King Solamona, who, having 'learned from the Hebrews that God had created the world and all that therein is in six days', also called it 'the College of the Six Days' Works' (58). These facts and the chronology they imply are not merely historical. That science is preceded at least by the teaching of the Hebrews - if not by Christianity - comports with Bacon's argument, spelled out in The Advancement of Learning, that genuine science required the mind's liberation from the tyranny of ancient thought, especially that of Plato and Aristotle. The basic problem of ancient thought was its pagan confusion of the natural and the divine, its belief that 'the world is an image of God and that man is an extract or compendious image of the world' ${ }^{3}$ According to Bacon, this confusion led to circular, empty, and fruitless teleological thinking, as well as to a misplaced reverence for nature. Ancient thought thus prevented our fathoming the true and often invisible causes at work in nature, and it inhibited the development of technological power: if nature is divine, we should not presume to transform it or see it as the source of limits to be overcome. Without the 'sacred truth' that the world, with the exception of man, is but a created thing and neither itself divine nor an image of the divine, genuine science and technology have no air to breathe. That science and technology should arise and flourish depends importantly on the genuine truth of the Biblical revelation.

Thus, as depicted in the New Atlantis, the modern project is crucially dependent on two fundamental miracles: the miracle of creation and the miracle of divine revelation. No wonder, then, that a central feature of the New Atlantis is a story about a miracle, told to the narrator to explain how the Bensalemites became Christians (47-9). According to the story, twenty years after the ascension of Christ, the Bensalemites saw a huge pillar of light, on top of which was a cross of more brilliant light, about a mile out to sea. The people gathered on the beach to wonder at the 'strange spectacle' and then approached it in boats. The boats were stopped, by some unseen force, some yards from the pillar, so that the Bensalemites were arrayed around it as if in a theatre 
and beheld the light 'as an heavenly sign'. A wise man of Salomon's House - presumably a natural scientist - was in one of the boats and, after having contemplated the pillar and cross 'attentively and devoutly', delivered a prayer to the 'Lord God of heaven and earth'. In the prayer, the wise man said that God has enabled the scientific establishment to know God's 'works of creation and the secrets of them, and to discern (as far as pertains to the generations of men) between divine miracles, works of nature, works of art, and impostures and illusions of all sorts'. The wise man then acknowledged and testified that the pillar was the finger of God and a 'true miracle' and said that 'forasmuch as we learn in our books that thou never workest miracles but to a divine and excellent end, (for the laws of nature are thine own laws, and thou exceedest them not but upon great cause,) we most humbly beseech thee to prosper this great sign, and to give us interpretation and use of it in mercy; which thou dost in some part secretly promise by sending it to us.'

At this point, and as if God answered the prayer immediately, the wise man's boat became free to approach the pillar. But before he reached it the pillar broke up, leaving but an ark floating in the water. In the ark was a book containing all the canonical books of the Old and New Testaments, the Apocalypse, and some other books of the New Testament that were not at that time written. The book was accompanied by a letter from St Bartholomew in which the Apostle testified that whoever found the ark received peace and salvation from Jesus and the Father. A final 'great miracle' then took place when some Hebrews, Persians, and Indians, who at that time lived in Bensalem, were able to read the book and the letter as if they had been written in their own languages.

Now, one of Bacon's concerns in telling this story is to establish the veracity of miracles. The Bensalemites, although they approach the pillar as a heavenly sign, must have been sensitive to a significant problem for believers, which is the sceptics' claim that miracles can be faked or explained away as misunderstood natural phenomena. The Bensalemites' answer is to rely not just on the internal evidence of the experience of faith, but also on the power of science to determine that an apparent miracle is not a natural, artificial, or illusory or deceitful event. This reliance 
explains why the miracle of the pillar of light is, in addition to its other features, a miracle of original revelation (it disclosed books of the New Testament that had not yet been written) and the gift of tongues. It is possible that Bensalemite scientists were present when Jesus performed his miracles and was resurrected. But so far as we know, or the Bensalemites admit, there were none present. There certainly were none present when Moses received the tablets of the law from God at Sinai. But in Bensalem, the narration of these at-the-time unverified events is supplied by a scientifically verified miracle, which is enough to establish their bona fides. Assume that Moses and Jesus were both frauds and that the parting of the Red Sea was but a timely, if rare, natural occurrence. If the representation of them as genuine miracles is itself a genuine miracle, that fact is by itself enough to establish that we should live as if they were genuine and that they could have been genuine miracles. The miracle that transpires in Bensalem is not just an adjunct to the miracles it discloses. It is, ultimately, the epistemic foundation of those prior miracles.

The problem is that it is impossible for science demonstrably to establish the reality of miracles. That there is no scientifically known cause for an apparent miracle does not establish that it is in fact a miracle, rather than just something we cannot yet explain by recourse to nature (including psychology). In order to prove scientifically and demonstrably that an event is supernatural, it would be necessary to have disclosed every single law and phenomenon of nature, every hidden cause and possibility. The Bensalemite scientist themselves, it seems, do not think such complete knowledge possible. For in his prayer the wise man of Salomon's House declares that God has given the scientists the power to know the works of divine creation and to discern between miracles and works of nature, art, and imposture and illusion 'as far as it appertaineth to the generations of men'. To this it could be objected that Bacon himself disagrees with this Bensalemite modesty. In The Advancement of Learning, Bacon says that Solomon's comment that man 'cannot ... find out the work which God worketh from the beginning to the end' refers not to the mind's capacity to grasp nature, but only to 'the impediments, as of shortness of life, ill conjunction of labours, ill tradition of knowledge over from hand to hand, and many other inconveniences 
whereunto the condition of man is subject' ${ }^{4}$ These inconveniences can be overcome with the right method and organisation of knowledge so that not just in principle, but also in practice, it is possible, within Bacon's scheme, to grasp the entirety of nature and hence to determine that an event is supernatural.

However, the attainment of such complete Baconian knowledge exacerbates a different impediment to discerning the reality of miracles. According to Bacon, 'human knowledge and human power meet in one. ${ }^{5}$ The courses of nature reveal themselves through the things that can be done by 'vexing' nature, and, in principle, nothing, short of creation ex nihilo, is beyond the power of human knowledge - including the 'restitution and renovation of things corruptible', i.e., the resurrection of the dead. ${ }^{6}$ The scientists of Bensalem themselves make this point in spades. The scientists of Salomon's House 'have so many things truly natural that induce admiration' that they 'could in a world of particulars deceive the senses, if [they] would disguise those things and labour to make them seem more miraculous' (80). Such fakery is forbidden and punished with ignominy and fines. But the fact is that the very knowledge that supposedly enables the scientists to determine the genuineness of miracles empowers them to commit successful religious fraud. Even a complete grasp of nature would still leave miracles with essentially the same status as the pre-scientific miracles of the Bible: dependent on the uncertain veracity of those who report or judge them. In fact the situation is worse. If one could imagine oneself transported to Sinai or Jerusalem at the times of Moses and Jesus, and one were, however otherwise hard-headed and sceptical, an actual witness to God's speaking to Moses or Jesus' rising up from the dead, one would be hard pressed not to believe the evidence of one's own eyes. Not so in Bensalem, where such things could actually happen by means of technology or be faked by means of technology.

As regards reason and miracles, Bacon reverses the usual order of things. Rather than claim reason and miracles to be at odds, he argues, quite dubiously, that reason can validate miracles. His reason for this move is not difficult to fathom. As he says in $O f$ Atheism, ${ }^{7}$ one cause of atheism is 'learned times, specially with peace and prosperity, for troubles and adversities do more bow men's minds to religion'. In a similar vein, 'a little philosophy 
inclineth man's mind to atheism'. In an enlightened and technologically enriched society, the people will be inclined to atheism, which, Bacon says, deprives man of his nobility and magnanimity: 'for certainly man is of kin to the beasts by his body; and, if he be not of kin to God by his spirit, he is a base and ignoble creature'. As we have seen, such atheism would also prevent our finding guidance for wielding the awesome power of technology. According to the essay, however, atheism is actually rare, because the mere sight of nature is enough to cause men to believe in God. As Bacon says, 'God never wrought miracle to convince atheism, because his ordinary works convince it.' To say that the people will be inclined to atheism, then, is not to say that atheism will necessarily become common. Much more likely is a certain weakening of faith, along with the spread of superstition, one cause of which is the taking aim at divine matters by human, which cannot but breed mixture of imaginations' ${ }^{8}$ The project of science surely takes aim at many matters thought to be divine not the least of which is death and resurrection - and so, by this argument, a technological society should be given to superstition. Moreover, while atheism would be dangerous for depriving technological power of guidance and for debasing human character, according to of Superstition, atheism is otherwise not really dangerous and 'did never perturb states'. Superstition, on the other hand, 'hath been the confusion of many states' and has ravished 'all the spheres of government'. Since 'the master of superstition is the people; and in all superstition wise men follow fools', it is well for the people to adhere to an orthodoxy supported by miracles verified by those whose power (other than God's) they revere and need the most - the natural scientists. Another cause of superstition is 'the stratagems of prelates for their own ambition and lucre'. In Bensalem, both the art and the authority of the scientists guarantee that the people believe, and that they do so in a way that puts the priests in their place.

In Bensalem, what could well be a noble lie told by scientists lends scientific credence to a miracle that could have been fabricated by the scientists themselves. Had the miracle never really happened, policy would have dictated its fabrication for at least the following reasons: it prevents the Bensalemites from descending into an utterly degraded materialism (they seem 
quite flat-headed enough), it allows for a general and tolerant orthodoxy and the consequent subordination and political integration of priests, and it provides the regulative principles for the enormous power unleashed by Bensalemite science and technology.

But a serious puzzle remains. First, there seems a tension between the ultimate goal of Bensalemite science (the restitution and renovation of corruptible things) and the basic teaching of Bensalemite religion: that death is the wages of sin. If there is a God, then Bensalemite science seems determined to put him out of business. Second, if it is true, as Bacon says, that human beings are base and ignoble without the kinship of the spirit to God, then a lot rides on the reality of miracles: if God and miracles exist, then human nature is characterised by the possibility of nobility and dignity. But if God and miracles do not exist, then such nobility and dignity rest on an illusion which, in principle, can be dispelled. Were it so, it would then be possible at least to contemplate a world based entirely on reason, in which there is nothing transcendent and noble to serve as a model for human behaviour and to which obeisance and sacrifice should be made. In such a rational world, the only principle of human action would be self-interest and only such self-interest as is material and can be satisfied by science and technology. This would be a world in which all interests could be harmonised, because they all can be indulged at the technological trough. Without miracles there can be nothing divine, and without the divine as a model there is nothing to us beyond those needs that can be satisfied by technology. As attractive as such a world is to us who suffer from unconquered nature, even Bacon indicates that, on reflection, we shudder at its prospect. ${ }^{9}$ So whether the miracle at the centre of the New Atlantis is or could be real, really matters. The answer tells us whether or not the possibilities of technology exhaust what human beings really are.

While the New Atlantis points to the impossibility of miracles, or at least to the impossibility of ever proving that they are real, nothing in the story allows us to say with certainty that miracles do not exist. Despite what the Bensalemites seem to think, science simply cannot settle the matter: while it cannot prove the existence of miracles, neither can it demonstrate their impossibility. It 
cannot establish, for example, that an explainable event might not, in fact and in a particular instance, be the product of a miraculous cause. So long as such uncertainty remains, the complete rationalisation and flattening of life need not be inevitable. It would still be possible to experience faith and heed the call of God and thus avoid the advent of a world devoid of human nobility and dignity. We would not be left dependent upon but a temporary and flimsy stopgap, such as a noble religious lie propagated by science.

There is a fly in this saving, agnostic ointment, however. As Bacon presents the miracle, natural science is not the only criterion for establishing its reality. When the wise man of Salomon's House pronounces the pillar to be a true miracle and the finger of God, he says that 'forasmuch as we learn in our books that thou never workest miracles but to a divine and excellent end (for the laws of nature are thine own laws and thou exceedest them not but upon great cause), we most humbly beseech thee to prosper this great sign, and to give us the interpretation and use of it in mercy; which thou dost in some part secretly promise by sending it unto us' (48). A miracle must not only be other than a work of nature, a work of art, an imposture, and an illusion. It must also be for a divine and excellent end. It must be for the good.

Now Bacon stresses over and over again that great damage to both reason and religion results from confusing the realms of the natural and the divine. This was, he says, the great defect of ancient (pagan) thought and as well of post-Christian thought to the extent that it was balefully influenced by the major ancient thinkers, Plato and Aristotle. Bacon argues accordingly that there is little we can learn about God from the study of nature. In The Advancement of Learning, Bacon says that natural theology is the 'knowledge of God that can be had by contemplating God's creatures'. But this knowledge is very limited: no light of nature, says Bacon, can declare the will and thus the worship of God. Just as any work of art shows the power and skill of the artisan, but not his image (who he is and why he made the artefact), so the natural works of God show his power and wisdom but not his image - not his will and purpose. All this said, however, Bacon then changes his mind, even in the immediate context. A few 
lines later, Bacon says that 'by the contemplation of nature to induce and enforce acknowledgement of God, and to demonstrate his power, providence, and goodness, is an excellent argument, and hath been excellently handled by diverse. ${ }^{\prime \prime o}$

One has to say that providence and goodness are no minor aspects of divine will - they are surely very important aspects of who God is and why he created the world and human beings. In the De augmentis, Bacon goes even further. There he says that the contemplation of nature discloses that God exists, that he is supremely powerful, that he is good, that he is a rewarder, that he is an avenger, and that he is an object of veneration. ${ }^{\text {II }}$ In other words, divine goodness and providence entail divine rewards and punishments. However, in The Advancement of Learning's later discussion of theology, Bacon says that with the light of nature we cannot understand the creation and the redemption and likewise the 'moral law truly interpreted' - the law that enjoins us to love our enemies, to do good to those who hate us, and to be like our heavenly Father who lets the rain fall on the just and the unjust. ${ }^{12}$ So it seems, after all, that nature by itself does not disclose God to be a rewarder and avenger: the rain falls on good and bad alike, the good die young and the wicked live to ripe old age.

Bacon's obvious and deliberate self-contradiction underscores a simple fact: people naïvely want nature to make moral sense and to exhibit divine care (even the Bensalemites think science can prove miracles). But nature - at least as regards our hopes and desires and prior to its conquest by technology - is a jungle where the strong eat the weak or, worse still, is a casino, where winners and losers are decided by sheer luck. The obvious lesson of the New Atlantis is that nature is inhospitable and indifferent to our needs, the object of conquest and not reverence. Miracles and miracles alone can disclose divine will, purpose, and care.

However, there is a connection between the naïve, erroneous interpretation of nature and our experience of divine miracles: the assumption of providence, of divine care, which must be good and, therefore, must reward the good and punish the bad. According to Bacon we do not learn this principle from miracles. We rather bring it to our faith and thereby to our experience of 
miracles, just as we bring it to our hopeful but erroneous experience of nature. According to Bacon, God never works miracles to convert atheists, but only to convert idolaters and the superstitious. In other words, the experience of miracles presupposes faith, which is one reason why reason and science, which reject faith out of hand, cannot disprove them. But again, our assumption about providence is neither itself miraculous nor revealed by a miracle, nor is it a matter of faith. It is rather an opinion about morality and what any god, if such were to exist, must be in this regard. And unlike faith, this opinion can be examined by reason.

Now about morality, Bacon has much to say. One such discussion is especially important for our purpose and occurs quite appropriately - in Bacon's consideration and refutation of the 'evil arts' of negotiation. These arts are represented by Machiavelli's infamous advice that one should possess the appearance of virtue rather than virtue itself, because having the reputation for virtue is a help but actually practising virtue is a hindrance, and that men can be ruled only by fear; by the Triumvirs' willingness to sacrifice their friends to gain the deaths of their enemies; by L. Catalina's willingness to use trouble of the states for pursuing his own fortune; or, finally, by the 'principle of Lysander' that children are to be deceived with candy and men by oaths. ${ }^{13}$

To refute these immoral maxims, Bacon says that if men 'be in their own power and do bear and sustain themselves' and are not 'carried away with a whirlwind or tempest of ambition', they should, in pursuing their fortunes, and in addition to keeping in mind the general principle about the world that 'all things are vanity and vexation of spirit', heed six 'particular cards and directions'. First, that virtue is most rewarded by itself, and vice most punished by itself. Second, that eternal providence and divine judgement often foil evil plots. Third, that even if one refrains from evil the ceaseless pursuit of fortune leaves no time for making tribute to God. Fourth, that we should not 'purpose' to use ill means for great ends, even though we might benefit from these ends. Fifth, that we should remember that fortune is like a woman in that if she be too much wooed she is the further off'. And finally, that such advice about fortune's woman-like 
character is for those already corrupted and that it is wise for men to build upon the corner stones of divinity and philosophy 'wherein they joint close'. The corner stone of divinity is that we should seek first the kingdom of God and the other things (that we seek in pursuing our fortunes) will follow. The corner stone of philosophy is that we should seek first the good of the mind and these same things will follow or not be wanted. ${ }^{14}$

There is much going on in this rich and compact discussion. But the important thing for us to note is that some of it is very fishy and surprisingly revealing. In his remarks introducing the six 'cards and directions', Bacon comments that we should follow them if we are in control of ourselves and not already in the grip of and carried away by ambition. The six good maxims are thus presented as if they are conditional and do not apply to those already in thrall to ambition. While it makes sense to proffer moral advice to those whom it can most benefit, it seems odd, then, not also to exhort those who, it would seem, most need that advice. Bacon argues as if nothing can be done for those already 'carried away' by ambition. Moreover, he says of them not that they are wicked, but rather that they are not 'in their own power' and do not 'bear and sustain themselves'. If so, however, it is hard to see how those who practise the evil arts can themselves be blamed for doing so. We do not blame those not in control of themselves - i.e., those who are not free to choose their maxims. If the sequel presents a lesson about virtue and vice, then it is preceded by at least the suggestion that while men may do things we call evil, they do so involuntarily and so cannot be responsible and thus morally blameworthy for their actions. So much for the first fish.

Even more fragrant are Bacon's comments regarding the first principle - that virtue is its own reward and wickedness its own punishment. Now this principle is at the heart of morality and is especially important for any refutation of Machiavelli. As homely and decent as it sounds, 'honesty is the best policy' is a maxim lethal to morality. It is a contingent statement of fact, which may or may not be true. At the very least, one could say that honesty is the best policy only on the debatable assumption that one's dishonesty will always be discovered and punished. Or it may be that honesty is in general and under normal 
conditions the best policy, but not good policy in extraordinary circumstances, such as when telling the truth would result in one's death or the death of loved ones or the death of innocent third parties (i.e., hostages on a hijacked plane). Such reasonable exceptions, however, give Machiavelli his basic point: that virtue is a useful means to some extrinsic end rather than an end in itself. This is of course why moralists admonish us to be good and virtuous for its own sake and not for some other end, such as happiness or things such as pleasure, money, fame, good reputation, the interest of one's nation or community, and so on. It is likewise why we tend to think that virtue at its peak, and when it really matters, requires self-sacrifice, and why virtue is diminished if performed for some payoff, even if that payoff is selfsatisfaction. Moreover, it simply isn't obvious that virtue is, merely in general, the best policy. Those who strive for virtue often lose out in life and the vicious often win ("nice guys finish last'). In politics, for instance, it is common for success to make scoundrels and even murderers into saints. And so if virtue is not good in itself and its own reward, then Machiavelli is right and virtue is but a useful tool and, ultimately, it is better to seem to be virtuous than actually to be so, especially in extreme circumstances.

It's no surprise, then, that Bacon's first move in refuting the evil arts of negotiation - and in particular Machiavelli - is to distinguish between the kinds of rewards and punishments associated with virtue. Rather than say that virtue is simply and only its own reward, he says that virtue is most rewarded in itself and vice most punished in itself. There are other, additional rewards and punishments (call them the add-ons). This distinction seems perfectly reasonable, since while we think that virtue is diminished when practised for some extrinsic end, we do think it would be a terrible world where the virtuous are miserable and simply food for the wicked. To emphasise his point, Bacon quotes lines from Virgil, ${ }^{15}$ in which, Bacon says, the poet 'excellently' makes this distinction between extrinsic rewards for virtue and virtue as its own, and higher and more essential, reward. However, the Virgilian lines make no such distinction.

In the context of the quote, the aged Aletes praises the Trojan warriors by saying that the first and best rewards will be 
paid to them by the gods and by their own worth and the rest will be paid by Aeneas and Ascanius. There are three kinds of rewards: divine, virtue's being its own reward, and rewards provided by men. According to Virgil, the divine rewards and virtue's being its own reward are the same - both are first and best. Now if virtue is good in itself and therefore its own reward, then divine rewards, whatever they may be, cannot be the same. They are add-ons. But what does it mean if virtue as its own reward and the divine add-ons are the same or, at least, are commensurable? In this world, it would mean that some sum of add-ons could surpass some sum of virtue-as-good-in-itself. Assuming the add-ons to be such things as happiness, pleasure, good reputation, all the good things in life, then it is entirely possible that virtue as its own reward could be outweighed by some combination of these add-on rewards, achieved by any means, and especially so if virtue required the sacrifice of life itself. In this case, then, Machiavelli wins: it is better to seem to be virtuous than actually to be so. Moreover, the only difference between the afterlife and this life - between worldly add-ons and add-ons as divine reward - is that in the afterlife the rewards are supposedly guaranteed to those who have been virtuous in life, and presumably are eternal and, perhaps, more intensely experienced in some way. However, even as divine rewards they would still be add-ons, and virtue would be a means to them. Machiavelli would win in principle, in that virtue would be a means rather than an end and good in itself, except that he would have erred in not taking divine providence into account.

Perhaps we could say that in heaven the add-ons are mere extras and that just being in heaven is utterly different from them and consists of the eternal experience of being virtuous as good in itself and thus of having it as its own reward. Here, I think, we reach the heart of the matter. How, we ask, does heavenly virtue differ from a perfect virtue in this world? In this world, the quintessence of virtue as good in itself is the sacrifice of one's all for another or for some noble end. In heaven, such virtue would consist in the eternal awareness of having sacrificed one's all in the world of mortal life. But if so, then the virtue in question cannot consist of pure self-sacrifice, either on earth or in heaven. It cannot be so on earth because of what awaits in 
heaven. And it cannot be so in heaven, because it consists not in the sacrifice of all, but in the experience (consciousness of, satisfaction at, pleasure in, etc.) of being virtuous. This experience obviously cannot be the sacrifice of all. It is, presumably, the greatest good that can come to human life and is thus no sacrifice at all. Even in heaven, the notion of virtue as good in itself and its own reward really makes no sense.

Now, what has the foregoing to do with the question of miracles and the New Atlantis? It reveals, I submit, the heart of the matter as Bacon understands it. As the second piece of advice or direction for refuting the evil arts, Bacon warns their practitioners that eternal providence and divine judgement often foil evil plots. It is not the most heartening advice, however, since God does not always thwart the bad guys. Indeed, as Bacon surely knows, it more often happens that the evil prosper and the innocent suffer. All the more reason, then, for the last piece of advice, which is that men should first seek the kingdom of God and remember that while human foundations have some sand mixed in, the 'divine foundation is upon the rock' ${ }^{16}{ }^{16}$ While we cannot understand God's specific purpose in the particular and mixed course of worldly events - God moves in mysterious ways, and for all we know has allowed the Bensalemites to use bad means for good secular ends - in the end et ista omnia adjicientur vobis ('and all these things shall be added unto you'). ${ }^{17}$ Even though the evil may prosper in this world, and while the ways and means of divine providence are often mysterious, there is no mystery at the end of days: the ultimate divine purpose is good, not bad. Nobody really thinks that God is an all-powerful monster who, for sport, plays with human beings as a boy plays with flies or ants.

That God is good, as the Bensalemites declare, is the opinion that grounds our faith and our experience of divine miracles. Fair enough. But Bacon seems to suggest that our very understanding of that goodness, especially as it bears on divine providence, is utterly confused. Our fundamental conception of what it means to be good is that goodness (or, to be more precise, moral goodness or virtue) is not a means for some other end and must be 'good in itself' - that it must be its 'own reward', to use Bacon's and the still common phrases. That we use these phrases 
interchangeably suggests that we cannot think of virtue as being good in itself without, in fact, also thinking of virtue in terms of reward. But reward and genuine virtue are incompatible. This probable confusion becomes a necessary contradiction when we think of divine providence. As regards divine providence, the very notion of virtue as good in itself is incoherent. We cling to this notion, quite rightly, as a bedrock moral intuition, and yet we cannot think of divine providence without betraying that somehow, barely consciously, we do not really believe, because we cannot believe, in such goodness-in-itself. We cannot conceive of divine providence without thinking of moral virtue as a means to other ends - to extrinsic rewards. When we think of divine goodness we cannot but mean that God is just, or, as Bacon says, that God rewards the virtuous and punishes the vicious. But if so, then God himself is a Machiavellian. Divine providence assumes that the good for man is a selfish good and that even selfsacrifice is ultimately selfish. Were this fact clear and not hidden in the mists of our moral confusions, it is not obvious that we could believe in such a God, especially if we take divine justice into account. For why would God punish those Machiavellians who, after all, agree with the divine notion that virtue is for the sake of rewards, who believe that virtue is not always the best means to those rewards, and who just happen not to believe that a God exists who ensures that, as a matter of ultimate fact, virtue is the best means to those rewards?

No sane person would choose to miss out on the ultimate rewards, and so it cannot be that unbelief is wilful. It's therefore not the unbeliever's fault that he does not believe, any more than one who is 'carried away with a whirlwind or tempest of ambition' is at fault for pursuing Machiavelli's selfish evil arts. ${ }^{18}$ Not only does divine providence reveal God to be a Machiavellian; it also reveals God to be one who punishes the innocent and rewards the lucky - and for no discernable good reason. Not even Machiavelli recommends that. Again, could anyone really believe in such a God? Could anyone believe in a God if they realised that his character is an affront to our deepest intuition about morality? Could anyone believe in a God after discovering that the moral horizon necessary for that god's miraculous revelation is incoherent? Bacon certainly sows some seeds of doubt. 
In the fifth and sixth pieces of advice for refuting the evil arts, Bacon warns the ambitious that fortune is like a woman and, for that reason, that we should seek the kingdom of God before and as a means to all other good things. These principles are surely not the first maxims of the Bensalemites, for whom the conquest of nature is the project of their kingdom. Moreover, the reference to Machiavelli, in the context of a refutation of the Machiavellian evil arts, is impossible to miss. Bacon obviously means for us to recall that, for Machiavelli, if fortune is a woman then 'it is necessary, if one wants to hold her down, to beat her and strike her down. And one sees that she lets herself be won more by the impetuous than by those who proceed coldly. And so always, like a woman, she is the friend of the young, because they are less cautious, more ferocious, and command her with more audacity.' ${ }^{\prime 9}$

This praise of youthful impetuosity and manly violence does not well suit the Bensalemites, who revere the old and seem overly sedate and orderly. For the Bensalemites, fortune is not the changeable political world and the mercurial ebb and flow of individual and group ambition. It is, rather, the hostile opposition of material nature to the basic human desire for long and commodious living. When the enemy is material nature rather than other human beings, the proper response is still something like the rape Machiavelli describes. For Bacon, the key to understanding and controlling nature is to put it on the rack. But for those who actually engage in it, the Bensalemite scientists, the assault on nature proceeds by an organised, methodical, dispassionate, and relatively anonymous process. Likewise for the non-scientific Bensalemites. While they probably do not understand or know much about natural science, they are not for that reason unaffected by it. As consumers of technological bounty, they are happy and contented. Bensalemite science - indeed the Baconian project for the conquest of nature - apparently overcomes the two main sources of political conflict: the material difference between haves and have-nots, and the psychological conflict between the strong and the weak. Thus, at least in principle, Bensalemite science and technology put an end to all questions of justice. What the strong want - the freedom and the means to understand and conquer nature - and what the weak want - the satisfaction of their material needs - go hand in hand. 
Now from what we know (or at least have conjectured) so far, as the concern for justice wanes in Bensalem, the importance and intensity of religion should wane as well. Indeed, the Bensalemites' religiosity already seems a tame and laid-back mish-mash: the Christians tolerate the Jews and the Jews believe in the divinity of Jesus, and officials dress like Turks and Persians. The Bensalemites are not yet atheists, probably because death has not yet been conquered. But given their technological conquest of scarcity and suffering, it is doubtful that they still have much truck with miracles. Why? Because they could have little or no concern for the issue at the heart of all credence in miracles: divine providence. Where there is no need to reward virtue and punish vice - since there is no need for the sacrifice of one's interests for another - there is no need for divine guidance, divine reminders, and divine rewards and punishments.

At this point one might well object that if the Bensalemites do not heed providence and, eventually, even become degraded and flat-headed atheists, so much the worse for them. That they cannot heed the divine call proves only that they cannot hear, not that there is no sound. True enough. Indeed, it seems doubtful that Bacon thought the denizens of the technological world to come would be the least bit self-reflective or profound. Their lack of religion would spring from satisfied indifference, not from genuine and deepening intellectual struggle or conviction. Their problem, if it were one, would concern the lack of motivation to be open to belief. However, Bacon's argument about the opinion necessary for belief is quite another matter. If Bacon is correct that our most basic intuitions about moral virtue are probably incoherent, and are certainly so when they serve as the necessary epistemic foundation of faith, then it cannot be said that a world of technological zombies can be redeemed by new gods - at least not by any gods that we could believe really exist. ${ }^{20}$

Why do we feel unease at the spectre of nature completely conquered? Because the resulting world would be so unrelentingly boring. What would its people do? They would shop. No god could intervene in and change this world, because life would afford no experience of virtue and vice, justice and injustice. The only alternative would be to break the scientific machine and, wilfully and artificially, to create new 'gods' by reintroducing 
the conditions of belief - an unlikely and scary possibility. Perhaps we should just be grateful that we are not yet at such a point, and that it is still a long way off.

\section{Notes}

I New Atlantis and The Great Instauration, ed. Jerry Weinberger (Wheeling, Illinois, Harlan Davidson, Inc., I980, revised edn I989), pp. 37-9, 56-8, 7I. All further references to New Atlantis come from this edition and will be cited in parentheses in the main body of my essay.

2 Thomas More, Utopia, eds George M. Logan and Robert M. Adams (Cambridge, Cambridge University Press, I989), pp. 8I-4; Plato Laws 77Ie, trans. Thomas L. Pangle (New York, Basic Books, Inc., I980), p. I59.

3 The Advancement of Learning, in The Works of Francis Bacon, ed. James Spedding, Robert Leslie Ellis, and Douglas Denon Heath, I4 vols. (London, Longman, I857-74) vol. III, pp. 349-50, 352-9.

4 The Advancement of Learning, p. 265.

5 Novum Organum I: 3, Bacon, Works, vol. IV, p. 47.

6 De sapientia veterum ('Of the Wisdom of the Ancients') XI, Bacon, Works, vol. VI, pp. 646, 72 I.

7 Bacon, Works, vol. VI, pp. 4I3-I5.

8 Of Superstition, in Bacon, Works, vol. VI, pp. 4I5-I6. Contemporary America comes to mind. In America full-bore materialism consists with widespread but mild religiosity and an abundance of religious novelty and other forms of spiritualism, including pantheism.

9 Nietzsche's chilling description of the Last Man and Heidegger's account of nihilism and technology come to mind. See, for example Nietzsche, Thus Spoke Zarathustra, The Portable Nietzsche, trans. Walter Kaufmann (New York, Vintage, I954), pp. I28-31; and Martin Heidegger, The Question Concerning Technology in The Question Concerning Technology and Other Essays, trans. William Lovitt (New York, Harper and Row, I97I), pp. 3-35.

Io The Advancement of Learning, pp. 349-5I.

I I De augmentis, 3:2, Bacon, Works, vol. IV, p. 34I.

I2 The Advancement of Learning, pp. 478-9.

I3 Ibid., pp. 47 I-2.

I4 Ibid., pp. 472-3.

I5 Aeneid 9: 252. Quae vobis, quae digna, viri, pro laudibus istis/praemia posse rear solvi? pulcherrima primum/di moresque dabunt vestri. 'What's worthy, you men, what prize for such laudable deeds? How can we pay you? Gods must give you the finest reward first - and your own character.' Slightly altered from Virgil, Aeneid, trans. Edward McCrorie (Ann Arbor, University of Michigan Press, 1995), p. 196. 
I6 The Advancement of Learning, p. 473.

I 7 Ibid, p. 473. Bacon's reference is to Matt 6:33.

I 8 The Advancement of Learning, p. 472.

I9 The Prince, XXV, trans. Harvey C. Mansfield (Chicago, University of Chicago Press, i985), p. Iог.

20 See Nur noch ein Gott kann uns retten ('Only a God Can Save Us Now'), Der Spiegel (May 3I, 1976), trans. Maria P. Alter and John D. Caputo in The Heidegger Controversy, ed. Richard Wolin (Cambridge, The MIT Press, I993), pp. 9I-II6. 